\title{
Phenolic Contents and Antioxidant Activities of Green Tea with and without Lemon
}

\author{
Ayat B. Al-Ghafari, Ayat M. Shorbaji, Lamya A. AL-Sarori, Eman 0. Baduwailan, \\ Aisha A. Basaar, Huda A. Al Doghaither, Hala F. Al-Marzouki, Ulfat M. Omar* \\ Department of Biochemistry, Faculty of Science, King Abdulaziz University, Jeddah, KSA \\ Email: *uomer@kau.edu.sa
}

Received 3 March 2016; accepted 14 June 2016; published 17 June 2016

Copyright (C) 2016 by authors and Scientific Research Publishing Inc.

This work is licensed under the Creative Commons Attribution International License (CC BY). http://creativecommons.org/licenses/by/4.0/

(c) (i) Open Access

\section{Abstract}

Tea is the most widely consumed beverage throughout the world, after water and is considered as a good antioxidant nutrient against free radical reactions. Lemons are citrus fruits that are very common in many parts of the world and are well known for their health benefits. In this study, different assays were used to evaluate total phenolic content and antioxidant activities of green tea with and without lemon. Our results showed that green tea with lemon has higher phenolic content, stronger reducing power than green tea without lemon; and exhibits a significant inhibition of 2,2-Diphenyl-1-picrylhydrazyl (DPPH) and hydrogen peroxide $\left(\mathrm{H}_{2} \mathrm{O}_{2}\right)$. However, both samples exhibited high ferrous chelating activity with no significant difference among each other indicating a good antioxidant potential for both. This is a comparative study between green tea and green tea supplemented with lemon. The study contributes to a better understanding about how the addition of supplements like lemon might influence the antioxidant activity of tea.

\section{Keywords}

Antioxidant Activity, Green Tea, Lemon, Metal Chelation, Phenolic Compounds, Radical Scavenging Component

\section{Introduction}

Tea is one of the most widely used beverages in the world and can be grouped into green, black, white, yellow, oolong and mate. It contains polyphenols, amino acids, proteins, carbohydrates, minerals, caffeine and other volatile compounds. Among the different types of tea, green tea (Camellia sinesis) is the most preferred type as it

"Corresponding author. 
has many benefits for human health [1]-[3]. Polyphenol, the main component of tea, consists of various types of catechin (C) [3], in particular, epicatechin (EC), epigallocatechin (EGC), epicatechin-3-gallate (ECG) and epigallocatechin-3-gallate (EGCG), which is the most active catechin in green tea [3]-[5]. Catechin compounds in fresh green tea leaves have been reported to have strong antioxidant activity in comparison with oolong and black tea leaves [4]. This is because green tea leaves are not fermented and catechin oxidation by polyphenol oxidase is prevented, while the oolong tea and the black tea leaves are either fermented to a limited extent or fully fermented, respectively [3] [4].

Lemon fruits (Citrus lemon) contain several kinds of flavonoids—a group of polyphenolic compound—such as flavone glycoside, flavanone glycoside and polymethoxyflavone [6] [7]. Moreover, it is an excellent source of vitamin C, an antioxidant that improves immune system and prevents oxidative stress related diseases [8] [9].

There are two methods to determine antioxidant capacity: the electron transfer and the hydrogen atom transfer. Folin-Ciocalteu, DPPH, hydrogen peroxide and reducing power are classified as electron transfer methods [10]. In this study, we aimed to compare the antioxidant activity of polyphenols in green tea and green tea supplemented with lemon using different spectrophotometric assays, to estimate the best type of tea that provides a better antioxidant effect. As far as we are aware, there are no studies that have been done on local Saudi green tea brand supplemented with lemon, to evaluate the total phenolic content and the antioxidant activity using five different mechanisms.

\section{Materials and Methods}

\subsection{Materials}

Classic green tea and green tea supplemented with lemon were obtained from Local Saudi Market, Folin-Ciocalteu's phenol reagent, anhydrous sodium carbonate, 2,2-Diphenyl-1-picrylhydrazyl (DPPH), ethanol, hydrogen peroxide, phosphate buffer saline (PBS), ascorbic acid, potassium ferricyanide, trichloroacetic acid (TCA), ferric chloride, ferrous chloride, Ferrozin and ethylenediaminetetraacetic acid (EDTA) were purchased from Sigma-Aldrich Chemical Co. (Pool, UK).

\subsection{Sample Preparation}

The experimental tea samples were prepared as traditionally consumed by Saudi people. A $10 \mathrm{mg} / \mathrm{ml}$ of each sample was prepared by adding hot boiling water to tea samples. The mixture was left for 10 minutes at room temperature, after that the antioxidant mechanisms were evaluated. Three different concentrations (2.5, 5 and 10 $\mathrm{mg} / \mathrm{ml}$ ) were prepared, to estimate the ability of different concentrations as reducing agents.

\subsection{Determination of Polyphenol by Follin Reagent}

The amount of total phenolic content was quantified according to Folin-Ciocalteu method [11]. First, 0.5 ml of each sample was transferred into test tubes and $5 \mathrm{ml}$ of deionized water was added to each sample. Then $0.5 \mathrm{ml}$ of Folin's reagent was added. The mixtures were left for 5 minutes at room temperature. After that, $1 \mathrm{ml}$ of $2 \%$ sodium carbonate solution was added to the mixtures and incubated for 1 hour in dark room. The color formed was measured at $750 \mathrm{~nm}$.

\subsection{DPPH Radical Scavenging Activity}

DPPH radical scavenging activity was measured by [12] method. First, $250 \mu$ l of each sample was added to 99.5\% ethanol. Then, $62.5 \mu \mathrm{l}$ of DPPH was added to the previous mixture and then incubated for 1 hour in dark place. The absorbance was measured at $517 \mathrm{~nm}$. Radical scavenging activity was expressed as inhibition percentage and was calculated using the following formula:

$$
\% \text { inhibition }=[(\mathrm{AB}-\mathrm{AA}) / \mathrm{AB}] \times 100
$$

where $(\mathrm{AB})=$ absorption of blank sample and $(\mathrm{AA})=$ absorption of sample.

\subsection{Hydrogen Peroxide Radical Scavenging Activity}

Scavenging activity of hydrogen peroxide was measured according to [13]. First, $1 \mathrm{ml}$ of the sample was added 
to $0.6 \mathrm{ml}$ of $40 \mathrm{mM}$ hydrogen peroxide. The absorbance value of the reaction mixture was recorded at $230 \mathrm{~nm}$. Radical scavenging activity was expressed as inhibition percentage and was calculated by the following equation:

$$
\% \text { inhibition }=[(\mathrm{AB}-\mathrm{AA}) / \mathrm{AB}] \times 100
$$

where $(\mathrm{AB})=$ absorption of blank sample and $(\mathrm{AA})=$ absorption of sample.

\subsection{Reducing Power}

The reducing power assay was performed as described by [14]. First, $2.5 \mathrm{ml}$ of $0.2 \mathrm{M}$ phosphate buffer $\mathrm{pH} 6.6$ and $2.5 \mathrm{ml}$ of $1 \%$ potassium ferric cyanide were added to $1 \mathrm{ml}$ of the sample and mixed well then incubated for 30 minutes at $50^{\circ} \mathrm{C}$. Then, $2.5 \mathrm{ml}$ of $10 \%$ Trichromoacetic acid was added to the previous mixture and centrifuged at $4^{\circ} \mathrm{C}$ for 10 minutes at $1600 \mathrm{rpm}$. After that, $2.5 \mathrm{ml}$ of the supernatant was mixed with $2.5 \mathrm{ml}$ deionized water and $0.5 \mathrm{ml}$ of $1 \%$ ferric chloride. The absorbance was measured at $700 \mathrm{~nm}$.

\subsection{Iron Chelating Activity}

The iron chelating activity was determined according to the procedure mentioned by [15]. A sample $500 \mu \mathrm{l}$ was added to $50 \mu \mathrm{l}$ of $2 \mathrm{mM}$ ferrous chloride and $1.5 \mathrm{ml}$ distilled, and then the mixture was vortexed for 30. A $100 \mu \mathrm{l}$ of $5 \mathrm{mM}$ Ferrozin was added to the previous mixture and was incubated for 10 minutes at room temperature. The absorbance was measured at $562 \mathrm{~nm}$. Ferrous ion chelating capacity was calculated using the following formula:

$$
\text { Chelating effect } \%=\left[\left(\mathrm{A}_{\text {control }}-\mathrm{A}_{\text {sample }}\right) / \mathrm{A}_{\text {control }}\right] \times 100
$$

\subsection{Statistical Analysis}

The data were statistically analyzed using GraphPad Prism 6. Results with $p<0.05$ were considered statistically significant. All experiments were performed in triplicate and the values were expressed as mean $\pm \mathrm{SD}$. The differences between the samples were assessed using unpaired t-test.

\section{Results}

\subsection{Total Polyphenol Content}

Total polyphenol content was estimated by Folin-Ciocalteu's method. Gallic acid was used as a standard. The content of polyphenols for green tea and green tea supplemented with lemon were 678.7 and 957.3 $\mu$ g of Gallic acid/10mg of tea, respectively showing that green tea supplemented with lemon has higher polyphenol contents than green tea.

\subsection{DPPH Radical Scavenging Activity}

Scavenging of DPPH is done by hydrogen/electron Transfer from a given antioxidant to DPPH [16]. The method is based on the reduction of alcoholic solution of the stable free radical DPPH by providing hydrogen atoms from antioxidant molecules to convert DPPH from radical form to non-radical form DPPH-H [17]. The percentages of inhibition caused by green tea and green tea supplement with lemon were $91 \%$ and $99 \%$ respectively. In this experiment, a significant reduction in the absorbance of DPPH radical was observed. Figure 1 shows that green tea with lemon has more effect in reducing DPPH radicals than green tea at the same concentration $\left(10 \mathrm{mg} \cdot \mathrm{ml}^{-1}\right)$.

\subsection{Hydrogen Peroxide Radical Scavenging Activity}

The ability of green tea and lemon to scavenge $\mathrm{H}_{2} \mathrm{O}_{2}$ was measured at $320 \mathrm{~nm}$. Since the samples contain phenolic compounds, $\mathrm{H}_{2} \mathrm{O}_{2}$ can be converted into $\mathrm{H}_{2} \mathrm{O}$ by donating electrons [17]. At $10 \mathrm{mg} \cdot \mathrm{ml}^{-1}$ concentration, green tea with lemon showed a significant $\mathrm{H}_{2} \mathrm{O}_{2}$ scavenging activity compared with green tea alone as shown in Figure 2. The percent of inhibition activity of $\mathrm{H}_{2} \mathrm{O}_{2}$ of green tea and green tea with lemon were $67 \%$ and $93 \%$, respectively. 


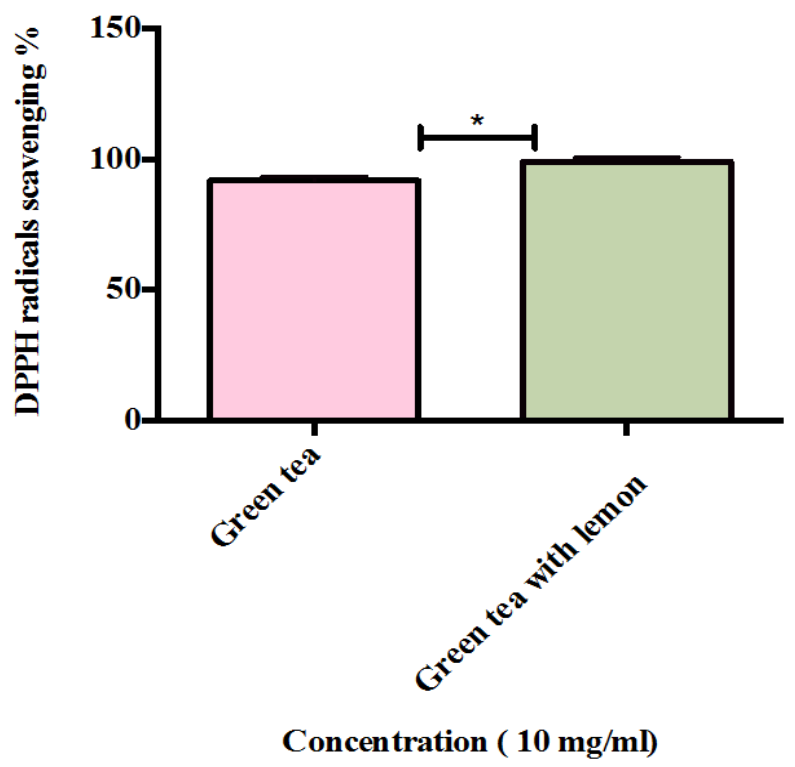

Figure 1. Radical scavenging activity of green tea without and with lemon. The value expressed as mean \pm SD $(n=3)$ of triplicate measurements. Comparisons of means were made using unpaired t-test $\left({ }^{*} p<0.05\right)$.

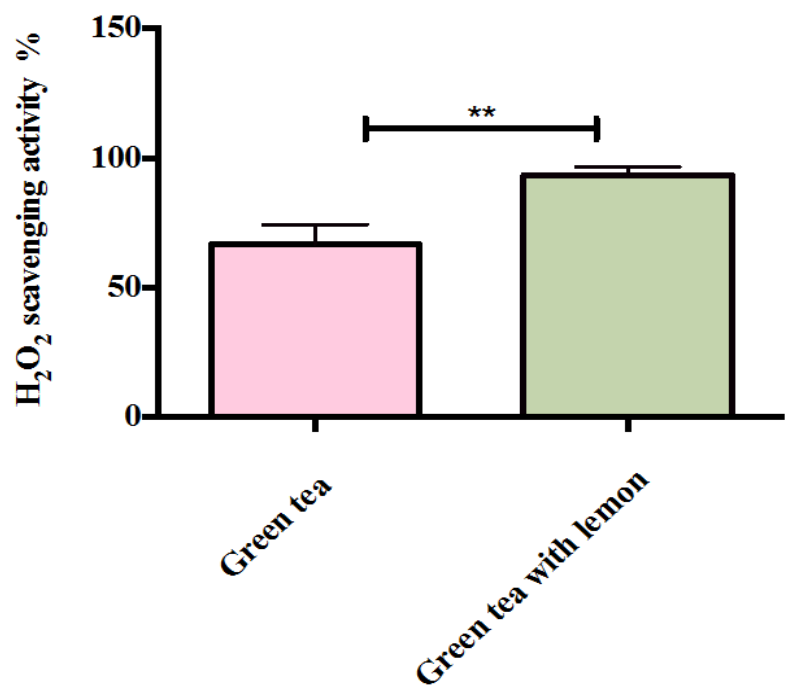

Concentration ( $10 \mathrm{mg} / \mathrm{ml}$ )

Figure 2. $\mathrm{H}_{2} \mathrm{O}_{2}$ scavenging activity of green tea without and with lemon. The value expressed as mean \pm SD $(n=3)$ of triplicate measurements. Comparisons of means were made using unpaired t-test $(* * p<0.005)$.

\subsection{Reducing Power}

In this experiment, the antioxidant compounds convert the oxidation form of iron $\left(\mathrm{Fe}^{+3}\right)$ in ferric chloride to ferrous $\left(\mathrm{Fe}^{+2}\right)$. The reducing powers of green tea and green tea supplemented with lemon were presented in Figure 3, and it is clearly shown that, with increased concentrations, the reducing power will also be increased. At all the tested concentrations, the reducing activity of green tea supplemented with lemon was significantly higher than that of green tea. The $p$ values were $0.03,0.0003$ and 0.03 for $2.5,5$ and $10 \mathrm{mg} \cdot \mathrm{ml}^{-1}$ respectively. 


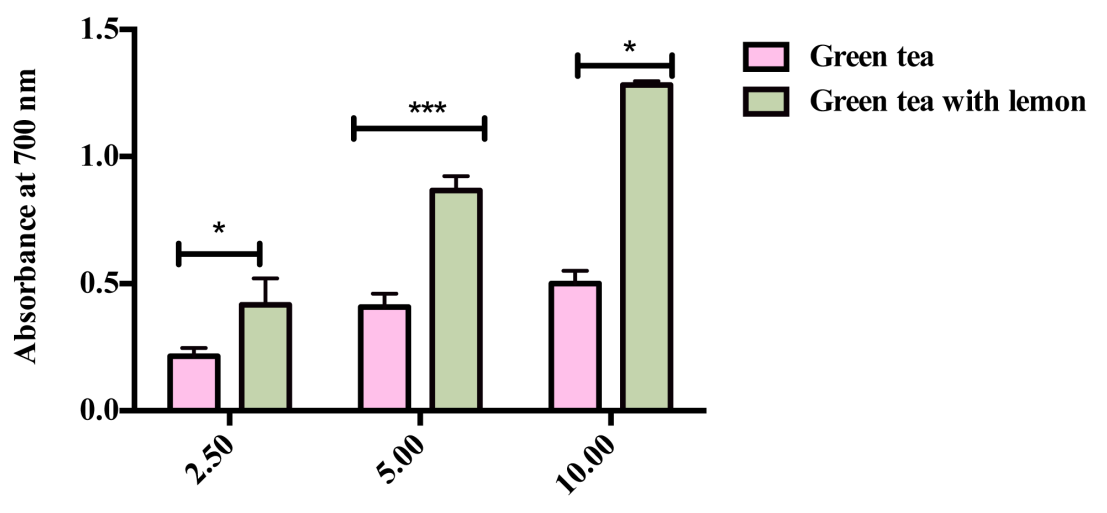

\section{Concentration $(\mathrm{mg} / \mathrm{ml})$}

Figure 3. Reducing power of different concentrations of green tea without and with lemon. The value expressed as mean \pm SD $(n=3)$ of triplicate measurements. Comparisons of means were made using unpaired t-test $\left({ }^{*} p<0.05\right.$ and ${ }^{* * *} p<$ 0.005).

\subsection{Iron Chelating Activity}

One of the mechanisms of antioxidant action is the chelation of transition metals that prohibiting stimulation of hydrogen peroxide dissociation [18]. This method is based on the inhibition of ferrous-ferrozin complex formation by the antioxidant compound present in the green tea and lemon. By comparing the two results, it can be seen that there is no significant difference in iron chelating activity at the same concentration $\left(10 \mathrm{mg} \cdot \mathrm{ml}^{-1}\right)$ in both samples (Figure 4).

The standard metal chelator agent used in this experiment was EDTA. Ferrous chelating activity of EDTA was $97 \%$ while for green tea and green tea with lemon, chelating activity were lower $83 \%$ and $84 \%$, respectively (Figure 5).

\section{Discussion}

Green, black and oolong tea are three different types of tea that different from each other by fermentation processing [4]. Black tea and oolong tea are fully fermented or semi fermented, respectively during fermentation process [4] [19]. However, green tea is not fermented. It is processed by preventing oxidation of catechin [19]. As a result, the flavanol group of polyphenols called catechins, the major bioactive compounds of green tea, are found in higher concentrations compared to black and oolong tea [4] [20]-[22]. Therefore, the order of antioxidant activity is: green tea $>$ oolong tea > black tea [19] [21]. Based on that, green tea has powerful antioxidantactivity which is responsible for important biological activity and have many health advantages [22] [23]. In general, many studies, reported the efficiency of green tea to scavenge free radicals. One study [24] reported that green tea has high radical scavenging ability by using DPPH free radical scavenging method. Previous studies showed that many bioactive compounds have been found in lemon such as phenolic acid, ascorbic acid, citric acid, limonoids, carotenoids, minerals and flavanone (hesperidin and naringin) [25] [26]. The benefits of polyphenols came from their high antioxidant capacity which prevents the development of many diseases associated with oxidative stress [27]. In our results, green tea with lemon showed more polyphenol contents than green tea and this might be due to the presence of additional phenolic compounds in lemon that increase the amount of antioxidantsin our body.

Flavonoids have a direct role in scavenging free radicals produced mostly as reactive oxygen species (ROS). [28] found that naringin, which is a part of lemon flavanone, can stimulate the immune system defenses to avoid oxidative damage caused by oxidation, by increasing the activity of the body's antioxidant enzymes including catalase, glutathione peroxidase and superoxide dismutase. These enzymes catalyze the dismutation of superoxide radical, which is the most common free radical in the body, into hydrogen peroxide $\left(\mathrm{H}_{2} \mathrm{O}_{2}\right)$. As a result, the addition of lemon might increase the ability of samples to reduce the amount of $\mathrm{H}_{2} \mathrm{O}_{2}$ [20]. A study performed by [29] showed that there is a relationship between flavonoid structure and their radical scavenging. The powerful 


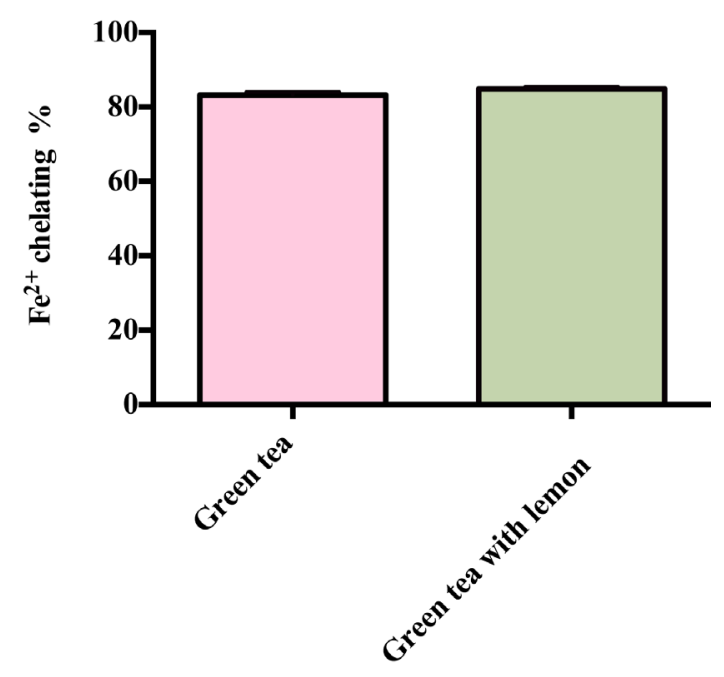

\section{Concentration ( $10 \mathrm{mg} / \mathrm{ml}$ )}

Figure 4. Ferrous chelating activity of green tea without and with lemon. The value expressed as mean $\pm \mathrm{SD}(\mathrm{n}=3)$ of triplicate measurements. Compression of means was made using unpaired t-test.

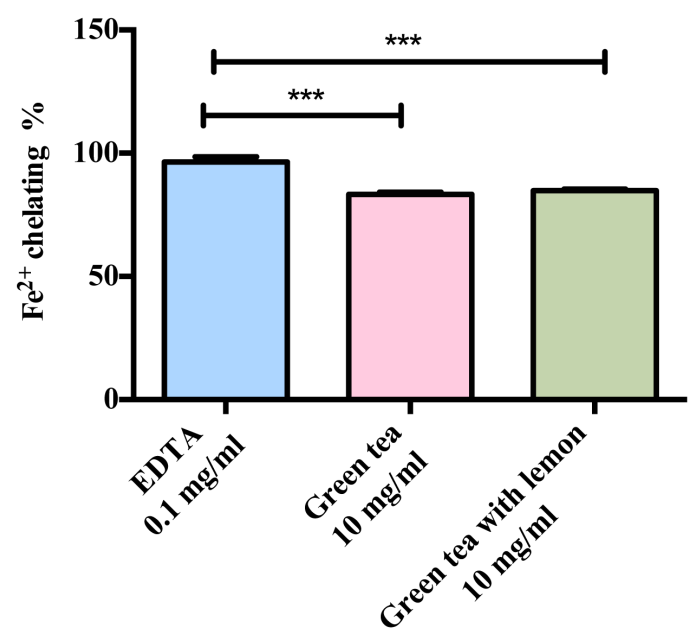

Figure 5. Ferrous chelating activity of green tea without and with lemon compared with EDTA at 0.1 $\mathrm{mg} \cdot \mathrm{ml}^{-1}$. The value expressed as mean $\pm \mathrm{SD}(\mathrm{n}=3)$ of triplicate measurements. Comparisons of means were made using a one-way ANOVA followed by Bonferroni's test $(* * * p<0.0005)$.

radical scavenging of lemon flavonoids is due to the presence of the ortho-dihydroxy structure in either ring A or ring $\mathrm{B}$, the hydroxyl moiety on position 3 in combination with the oxo group at position 4 and the presence of a C2-C3 double bond in ring $\mathrm{C}$ as shown in Figure 6.

For that, this flavonoid has the ability to scavenge DPPH free radicals by rapidly donating hydrogen atom from hydroxyl group to radicals and it is visually noticeable by the change in the color from purple to yellow as shown in Figure 7.

Furthermore, several studies reported that lemon has other important natural chemical components including limonoids, carotenoids, phenolic acid and pectin that also have different levels of free radical scavenging. These components can neutralize free radicals and therefore prevent some of the damages caused by free radicals 


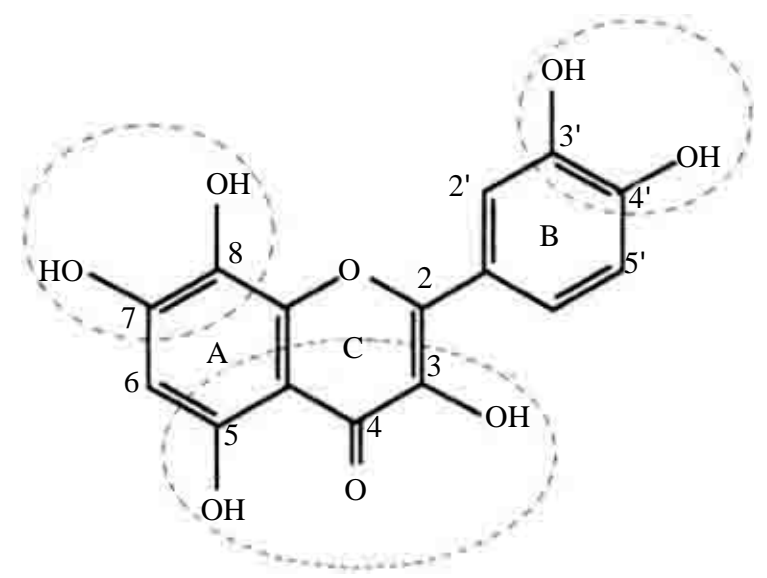

Figure 6. Structural features of flavonoid with a high radical scavenging activity [29].

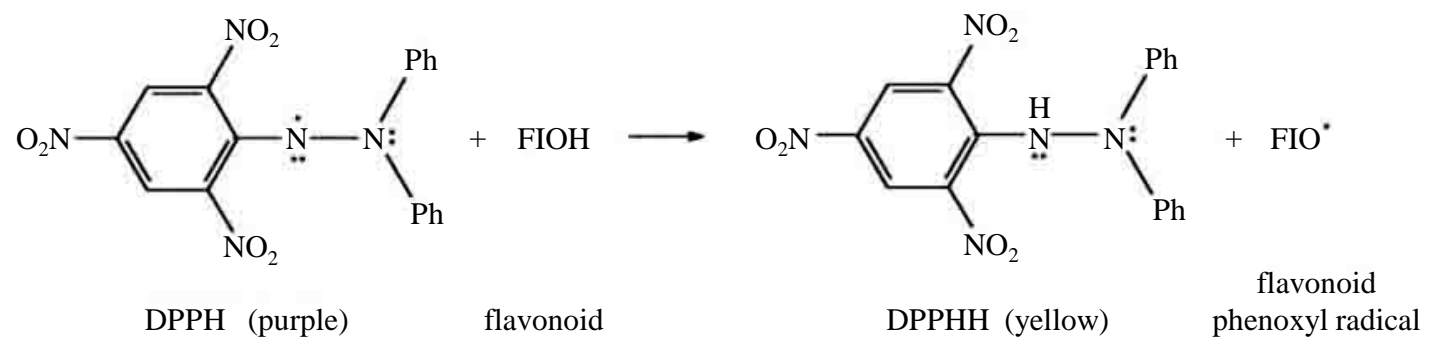

Figure 7. Scavenging of DPPH free radical by a flavonoid [29].

[30]-[32]. From all these studies, we noticed that there is a relationship between the scavenging activity and the flavonoid content of lemon [28]. This explains to some degree why green tea supplemented with lemon has more ability to scavenge free radical than green tea alone. Reducing power of bioactive compounds may serve as a significant reflection of its potential antioxidant activity [8]. Compounds with reducing power can act as electron givers and can react with free radicals to become steady and prevent radical chain reaction [33]. Therefore, the reducing activity of green tea supplemented with lemon was significantly higher than that of green tea.

Our results in iron chelating activity assay showed that the ability of lemon to chelate iron was weak. In agreement with our results, the study by [34], indicated that naringin did not chelate iron completely because it was incapable to overrun all active sites of iron. Moreover, a study by [35] indicated that citric acid, which is the main component of lemon, was not a good chelating agent for ferrous ion and its chelating ability was low. The high chelating iron activity in our results derived from green tea might be due to the specific functional group in its catechin flavanols structure [35].

\section{Conclusion}

In conclusion, our results indicated that green tea supplemented with lemon has a better antioxidant activity compared to green tea without lemon supplementation, due to the presence of additional phenolic compound in lemon. Further researches are needed using different tea brands with different supplements, in order to estimate the best type of tea supplementation that provides the optimal antioxidants for potential health benefits.

\section{Acknowledgements}

The research team would like to thank Science Research \& Innovation Unit at the Faculty of Science, King Abdulaziz University for supporting this work

\section{References}

[1] Jiang, H., Engelhardt, U.H., Thräne, C., Maiwald, B. and Stark, J. (2015) Determination of Flavonol Glycosides in 
Green Tea, Oolong Tea and Black Tea by UHPLC Compared to HPLC. Food Chemistry, 183, 30-35. http://dx.doi.org/10.1016/j.foodchem.2015.03.024

[2] Majchrzak, D., Mitter, S. and Elmadfa, I. (2004) The Effect of Ascorbic Acid on Total Antioxidant Activity of Black and Green Teas. Food Chemistry, 88, 447-451. http://dx.doi.org/10.1016/j.foodchem.2004.01.058

[3] Quan, P.T., Hang, T.V., Ha, N.H. and Giang, B.L. (2007) Total Polyphenols, Total Catechins Content and DPPH Free Radical Scavenger Activity of Several Types of Vietnam Commercial Green Tea. Science Technology Development, 10, 5-11.

[4] Anesini, C., Ferraro, G.E. and Filip, R. (2008) Total Polyphenol Content and Antioxidant Capacity of Commercially Available Tea (Camellia sinensis) in Argentina. Journal of Agricultural and Food Chemistry, 56, 9225-9229. http://dx.doi.org/10.1021/jf8022782

[5] Taheri, M., Giahi, M., Shahmohamadi, R., Ghafoori, H., Aghamaali, M.R. and Sariri, R. (2011) Screening Antioxidant Activity of Extracts from Different Tea Samples. Pharmacologyonline, 3, 442-448.

[6] Fukuchi, Y., Hiramitsu, M., Okada, M., Hayashi, S., Nabeno, Y., Osawa, T. and Naito, M. (2008) Lemon Polyphenols Suppress Diet-Induced Obesity by Up-Regulation of mRNA Levels of the Enzymes Involved in $\beta$-Oxidation in Mouse White Adipose Tissue. Journal of Clinical Biochemistry and Nutrition, 43, 201-209. http://dx.doi.org/10.3164/jcbn.2008066

[7] Shaghaghi, M., Manzoori, J.L. and Jouyban, A. (2008) Determination of Total Phenols in Tea Infusions, Tomato and Apple Juice by Terbium Sensitized Fluorescence Method as an Alternative Approach to the Folin-Ciocalteu Spectrophotometric Method. Food Chemistry, 108, 695-701. http://dx.doi.org/10.1016/j.foodchem.2007.11.008

[8] Kanatt, S.R., Chawla, S.P. and Sharma, A. (2014) Antioxidant and Radio-Protective Activities of Lemon Grass and Star Anise Extracts. Food Bioscience, 6, 24-30. http://dx.doi.org/10.1016/j.fbio.2014.03.002

[9] Kim, J., Jayaprakasha, G.K. and Patil, B.S. (2013) Limonoids and Their Anti-Proliferative and Anti-Aromatase Properties in Human Breast Cancer Cells. Food \& Function, 4, 258-265. http://dx.doi.org/10.1039/C2FO30209H

[10] Gorjanović, S., Komes, D., Pastor, F., Belşçak-Cvitanović, A., Pezo, L., Heçimović, I. and Suz̧njević, D. (2012) Antioxidant Capacity of Teas and Herbal Infusions: Polarographic Assessment. Journal of Agricultural and Food Chemistry, 60, 9573-9580. http://dx.doi.org/10.1021/jf302375t

[11] Kim, D., Chun, O.K., Kim, Y.J., Moon, H. and Lee, C.Y. (2003) Quantification of Polyphenolics and Their Antioxidant Capacity in Fresh Plums. Journal of Agricultural and Food Chemistry, 51, 6509-6515. http://dx.doi.org/10.1021/jf0343074

[12] Bersuder, P., Hole, M. and Smith, G. (1998) Antioxidants from a Heated Histidine-Glucose Model System. I: Investigation of the Antioxidant Role of Histidine and Isolation of Antioxidants by High-Performance Liquid Chromatography. Journal of the American Oil Chemists' Society, 75, 181-187. http://dx.doi.org/10.1007/s11746-998-0030-y

[13] Gülçin, I., Alici, H.A. and Cesur, M. (2005) Determination of in Vitro Antioxidant and Radical Scavenging Activities of Propofol. Chemical \& Pharmaceutical Bulletin, 53, 281-285. http://dx.doi.org/10.1248/cpb.53.281

[14] Yıldırım, A., Mavi, A., Oktay, M., Kara, A.A., Algur, Ö.F. and Bilaloğlu, V. (2000) Comparison of Antioxidant and Antimicrobial Activities of Tilia (Tiliaargentea desf ex DC), Sage (Salvia triloba L.), and Black Tea (Camellia sinensis) Extracts. Journal of Agricultural and Food Chemistry, 48, 5030-5034. http://dx.doi.org/10.1248/cpb.53.281

[15] Dinis, T.C.P., Maderia, V.M.C. and Almeida, L.M. (1994) Action of Phenolic Derivatives (Acetaminophen, Salicylate, and 5-Aminosalicylate) as Inhibitors of Membrane Lipid Peroxidation and as Peroxyl Radical Scavengers. Archives of Biochemistry and Biophysics, 315, 161-169. http://dx.doi.org/10.1006/abbi.1994.1485

[16] Anissi, J., El Hassouni, M., Ouardaoui, A. and Sendide, K. (2014) A Comparative Study of the Antioxidant Scavenging Activity of Green Tea, Black Tea and Coffee Extracts: A Kinetic Approach. Food Chemistry, 150, 438-447. http://dx.doi.org/10.1016/j.foodchem.2013.11.009

[17] Shon, M.Y., Kim, T.H. and Sung, N.J. (2003) Antioxidants and Free Radical Scavenging Activity of Phellinus baumii (Phellinus of Hymenochaetaceae) Extracts. Food Chemistry, 82, 593-597. http://dx.doi.org/10.1016/S0308-8146(03)00015-3

[18] Dastmalchi, K., Dorman, H.J.D., Oinonen, P.P., Darwis, Y., Laakso, I. and Hiltunen, R. (2008) Chemical Composition and in Vitro Antioxidative Activity of a Lemon Balm (Melissa officinalis L.) Extract. LWT-Food Science and Technology, 41, 391-400. http://dx.doi.org/10.1016/j.lwt.2007.03.007

[19] Tran, J. (2013) Green Tea: A Potential Alternative Anti-Infectious Agent Catechins and Viral Infections. Advances in Anthropology, 3, 198-202. http://dx.doi.org/10.4236/aa.2013.34028

[20] Ayabe, S. and Aoshima, H. (2007) Aqueous Extract of Citrus Peel Reduces Production of Hydrogen Peroxide in Catechin-Enriched Green Tea. Food Chemistry, 104, 1594-1598. http://dx.doi.org/10.1016/j.foodchem.2007.03.009

[21] Carloni, P., Tiano, L., Padella, L., Bacchetti, T., Customu, C., Kay, A. and Damiani, E. (2013) Antioxidant Activity of 
White, Green and Black Tea Obtained from the Same Tea Cultivar. Food Research International, 53, 900-908. http://dx.doi.org/10.1016/j.foodres.2012.07.057

[22] Sutherland, B.A., Rahman, R.M. and Appleton, I. (2006) Mechanisms of Action of Green Tea Catechins, with a Focus on Ischemia-Induced Neurodegeneration. Journal of Nutritional Biochemistry, 17, 291-306. http://dx.doi.org/10.1016/j.jnutbio.2005.10.005

[23] Takumi-Kobayashi, A., Ogura, R., Morita, O., Nishiyama, N. and Kasamatsu, T. (2008) Involvement of Hydrogen Peroxide in Chromosomal Aberrations Induced by Green Tea Catechins in Vitro and Implications for Risk Assessment. Mutation Research/Genetic Toxicology and Environmental Mutagenesis, 657, 13-18. http://dx.doi.org/10.1016/j.mrgentox.2008.08.016

[24] Gramza, A., Pawlak-Lemańska, K., Korczak, J., Wasowicz, E. and Rudzinska, M. (2005) Tea Extracts as Free Radical Scavengers. Polish Journal of Environmental Studies, 14, 861-867.

[25] Del Rio, J.A., Fuster, M.D., Gomez, P., Porras, I., Garcia-Lidon, A. and Ortuno, A. (2004) Citrus Limon: A Source of Flavonoids of Pharmaceutical Interest. Food Chemistry, 84, 457-461. http://dx.doi.org/10.1016/S0308-8146(03)00272-3

[26] Sun, Y., Shen, Y., Liu, D. and Ye, X. (2015) Effects of Drying Methods on Phytochemical Compounds and Antioxidant Activity of Physiologically Dropped Un-Matured Citrus Fruits. LWT_Food Science and Technology, 60, 12691275. http://dx.doi.org/10.1016/j.lwt.2014.09.001

[27] Cyboran, S., Strugała, P., Włoch, A., Oszmiański, J. and Kleszczyńska, H. (2015) Concentrated Green Tea Supplement: Biological Activity and Molecular Mechanisms. Life Sciences, 126, 1-9. http://dx.doi.org/10.1016/j.lfs.2014.12.025

[28] Zou, Z., Xi, W., Hu, Y., Nie, C. and Zhou, Z. (2015) Antioxidant Activity of Citrus Fruits. Food Chemistry, 196, 885896. http://dx.doi.org/10.1016/j.foodchem.2015.09.072

[29] Seyoum, A., Asres, K. and El-Fiky, F.K. (2006) Structure-Radical Scavenging Activity Relationships of Flavonoids. Phytochemistry, 67, 2058-2070. http://dx.doi.org/10.1016/j.phytochem.2006.07.002

[30] Dai, J. and Mumper, R.J. (2010) Plant Phenolics: Extraction, Analysis and Their Antioxidant and Anticancer Properties. Molecules, 15, 7313-7352. http://dx.doi.org/10.3390/molecules15107313

[31] Di Mascio, P., Kaiser, S. and Sies, H. (1989) Lycopene as the Most Efficient Biological Carotenoid Singlet Oxygen Quencher. Archives of Biochemistry and Biophysics, 274, 532-538. http://dx.doi.org/10.1016/0003-9861(89)90467-0

[32] Koriem, K.M.M., Arbid, M.S. and Emam, K.R. (2014) Therapeutic Effect of Pectin on Octylphenol Induced Kidney Dysfunction, Oxidative Stress and Apoptosis in Rats. Environmental Toxicology and Pharmacology, 38, 14-23. http://dx.doi.org/10.1016/j.etap.2014.04.029

[33] Kamdem, J.P., Adeniran, A., Boligon, A.A., Klimaczewski, C.V., Elekofehinti, O.O., Hassan, W., Ibrahim, M., Waczuk, E.P., Meinerz, D.F. and Athayde, M.L. (2013) Antioxidant Activity, Genotoxicity and Cytotoxicity Evaluation of Lemon Balm (Melissa officinalis L.) Ethanolic Extract: Its Potential Role in Neuroprotection. Industrial Crops and Products, 51, 26-34. http://dx.doi.org/10.1016/j.indcrop.2013.08.056

[34] Jagetia, G.C. and Reddy, T.K. (2011) Alleviation of Iron Induced Oxidative Stress by the Grape Fruit Flavano nenaringin in Vitro. Chemico-Biological Interactions, 190, 121-128. http://dx.doi.org/10.1016/j.cbi.2011.02.009

[35] Lin, S.D., Liu, E.H. and Mau, J.L. (2008) Effect of Different Brewing Methods on Antioxidant Properties of Steaming Green Tea. LWT_Food Science and Technology, 41, 1616-1623. http://dx.doi.org/10.1016/j.lwt.2007.10.009 